\title{
Reconnecting the space of tourism and citizenship: the case of tourists' hubris
}

Lucia Tomassini, Leanne Schreurs and Elena Cavagnaro

\begin{abstract}
Purpose - The rapid growth of tourism prior to the COVID-19 pandemic prompts the need for critical reflection of tourism's "local-global" responsibility in the wake of that pandemic. Conceptually driven by the ancient Greek notion of hubris, this study reflects on the perception of tourists as actors disconnected from citizens' necessities, safety and well-being. In so doing we develop further knowledge on the relationship between the spaces of tourism and citizenship and how this might build a sustainable future-proof tourism.

Design/methodology/approach - Data were collected daily for two weeks via three Google Alert queries set to mine Italian online news media contents immediately after the Italian Government's adoption of mobility restrictions due to COVID-19. This study uses a thematic narrative analysis to examine the contents related to tourists during the COVID-19 outbreak.

Findings - The exploratory findings reveal how tourists are largely presented as taking over the space of local residents and, by breaking the rules set by national and local authorities, as disregarding those residents' safety and well-being. Hence, they appear disconnected from any sense of belonging to a local or global community, and from a space to which they owe a duty of care.

Originality/value - By framing tourists as hubristic subjects ontologically belonging to a neoliberal leisure space disentangled from the citizenship space, this study establishes a novel theoretical grounding from which a sustainable future-proof tourism that is rooted in citizenship space can be rethought.
\end{abstract}

Keywords Citizenship, Neoliberalism, Sustainable tourism, COVID-19, Hubris, Sociology of space Paper type Research paper

\section{Introduction}

The rapid growth of tourism (UNWTO, 2020) has spurred debate on the global challenges and issues triggered by the tourism industry in a neoliberal globalized world characterized by an intense mobility of people, capital and goods (Boluk et al., 2019). The tourism industry is highly representative of the neoliberal global economy and is largely understood as an expression of a fluid society characterized by fragmentation, growing injustice and social and economic inequalities (Bianchi, 2018; Burrai et al., 2019; Higgins-Desbiolles et al., 2019; Jamal, 2019). In particular, the uncontrolled growth of tourism - i.e. "overtourism" (Milano et al., 2019) - and badly-behaved tourists (Higgins-Desbiolles, 2019) have been perceived as exacerbating already unbalanced power-relationships in the neoliberal order, alienating citizens from their own spaces (Diaz-Parra and Jover, 2020). The COVID-19 pandemic crisis has now intruded into this troubled context, uncovering both old and new fragilities of contemporary tourism and further highlighting the need for a critical reflection on its "local-global" responsibility (Jamal and Budke, 2020). While that crisis has raised new uncertainties and fears with regards to the future development and state of our society, the global economy and personal freedom, it also represents an opportunity for a deeper reflection on the future of tourism, as has recently been extensively discussed in the Tourism Geographies Special Issue "Visions of travel and tourism after the global COVID-19 Transformation of 2020" (Lew et al., 2020).
Lucia Tomassini, Leanne Schreurs and Elena Cavagnaro are all based at the NHL Stenden University of Applied Sciences, Leeuwarden, The Netherlands.

Received 21 October 2020 Revised 5 March 2021 6 April 2021 11 April 2021 Accepted 13 April 2021

(C) Lucia Tomassini, Leanne Schreursa and Elena Cavagnaroa. Published in Journal of Tourism Futures. Published by Emerald Publishing Limited. This article is published under the Creative Commons Attribution (CC BY 4.0) licence. Anyone may reproduce, distribute, translate and create derivative works of this article (for both commercial and non-commercial purposes), subject to full attribution to the original publication and authors. The full terms of this licence may be seen at http://creativecommons.org/licences/by/4.0/ legalcode 
Building on the notion of hubris, we explore the gap between the spaces of tourism and those of citizenship by investigating the perception of tourists and travelers as individuals disconnected from the space of citizenship. We build on Lefebvre's theorization of the production of social space (1984) and Massey's $(2005,2009)$ conceptualization of "space" as the dimension of the social and the result of an ongoing process of multiple connections, interactions and power-relationships. Tourists have often been understood both as anonymous "products" in transit through a space conceived as a flat surface (Tomassini and Cavagnaro, 2020), and as an overwhelming number of individuals - framed as the "overtourism" phenomenon - travelling and acting without any sense of local or global responsibility (Cheer et al., 2019; Gössling et al., 2020; Milano et al., 2019; Phi, 2019), and, thanks to online short-term rental platforms, increasingly penetrating into the residential city space (Celata and Romano, 2020). As it is impossible to be both a tourist and a dweller at the same time or in the same space (D'Eramo, 2017; Tomassini and Cavagnaro, 2020), contemporary tourists and travelers appear as an epitome of neoliberal capitalism and consumerism, often putting at risk the safety and well-being of the local and global community (Higgins-Desbiolles, 2006, 2020; Jover and Díaz-Parra, 2020; Kirtsoglou and Theodossopoulos, 2004).

Our exploration of the gap between the space of tourism and that of citizenship starts from an historical perspective, tracing the origins of "tourism" (Hall and Page, 2010; Korstanje, 2007; Leiper, 1983) in the otium "leisure" dimension of the ancient Roman civis "citizen" (Gawthrop and Waldo, 1984; Korstanje, 2007; Morris, 2008; White, 2016). This goes on showing how the advent of modern tourism can be conceptualized in terms of commodities consumption (Borocz, 1992), and how contemporary neoliberal tourism has been widely discussed as an industry rooted in neoliberal market-driven growth, spreading social inequalities and injustice (Higgins-Desbiolles, 2006, 2020). To study the gap between the space of tourism and the space of citizenship, we use the lens of the ancient Greek notion of hubris, exemplified in the heroes of classical Greek tragedy where overconfidence and arrogance lead them to overstep the boundaries fitting for human action (Fisher, 2015; Marquez, 2014; Cohen, 1991). More specifically, in Aristotle's Politics (1968), hubris is actually the characteristic of a man incapable of working with others to pursue the community's well-being. The contemporary tourists' and travelers' disconnection from citizens' needs and well-being is thus investigated by interweaving the notion of hubris with Lefebvre's (1984) and Massey's (2005, 2009) theorizations on space.

Therefore, we investigate the extent to which tourists during the COVID-19 pandemic are understood and narrated as irresponsible citizens disconnected from any sense of belonging to a local or global community and space to which they owe a duty of care. In so doing, we seek to set out a novel theoretical ground to reconnect tourist and citizen space and build a future-proof sustainable tourism that can counteract the global threat posed by the 21st century trend of the "tourist syndrome" (Bauman, 2000; Franklin, 2003), with its implications in respect to growing injustice and social and economic inequality.

\section{Context}

In March 2020, Italy was the first country in the Western world to experience an intense COVID-19 outbreak, resulting in a strict lockdown where Italian citizens were instructed - by law enforcement and national security measures - to remain at home, avoiding any form of mobility not justified by job or health necessities. This research is grounded in an exploratory narrative analysis of the debate that emerged in online Italian news media immediately after the approval of the Italian Government Decree on 8th March 2020 that initiated the lockdown. A Google Alert query based on a number of predefined keywords allowed daily monitoring of the contents of online news media reports about tourists and travelers during the period of mobility restrictions. 


\section{A theoretical framework of space and hubris}

The theoretical framework employed interweaves a critical reflection on the sociological notion of space, guided by the work of Lefebvre (1984) and Massey $(2005,2009)$, with an historical overview of the relationship between the spaces of tourism and citizenship, and the gap between the two established by neoliberal capitalism. We combine the aforementioned theoretical framework with the ancient Greek notion of hubris, described as a dangerous pride and lack of awareness of the proper limits assigned to human beings who, unable to work within and for the well-being of the local and global community to which they belong, overstep their boundaries (Cohen, 1991; Grigoriadis, 2011). The notion of Hubris is applied to interpret the gap between the tourist and citizen spaces by framing tourists as hubristic human beings, transcending the sociological space of their fellow citizens, and as hubristic subjects ontologically belonging to a neoliberal leisure space disentangled from the citizenship space.

\section{Space of tourism and of citizenship: a historical perspective}

The concept of "space" is here used in accordance with Lefebvre's epistemology examining "the active - operational or instrumental - role of space, as knowledge and action, in the existing mode of production" (1984, p. 11). Lefebvre (1984) claims that space is socially constructed; therefore, every society and every mode of production creates a certain space, its own space. "The space thus produced serves as a tool of thought and action; that in addition to being a means of production, it is also a means of control, and hence of domination, of power; yet that, as such, it escapes in part from those who would make use of it" (Lefebvre, 1984, p. 26). Lefebvre's (1984) understanding of space as socially constructed and soaked in power resonates with Massey's $(2005,2009)$ ruminations theorizing "space" as the dimension of multiplicity, the result of relations, connections, networks and exchanges; always ongoing. As the dimension of the social, space is imbued with relations of power - Massey $(2005,2009)$ calls them "powergeometries" - since power is in itself relational. This conceptualization of space reveals how neoliberal globalization has arguably produced its own space as a "flat" surface that people, capital and products transit every day as efficiently as possible. Space itself has consequently largely become a commodified entity (Lefebvre, 1976, 1984; Massey, 1992, 1999). This neoliberal approach to the notion of space, moreover, discloses the fragmentation and rationalization of our lives in terms of the physical and temporal separation of their different moments, including a separation between the spatial dimensions of citizens and tourists (Celata and Romano, 2020; D'Eramo, 2017; Gainsforth, 2019; Sun et al., 2020; Tomassini and Cavagnaro, 2020). The fragmentation of our lives as rootless individuals living many different experiences limited in time and space, is what Zygmunt Bauman defines as the "tourism syndrome" (Bauman, 2000; Franklin, 2003).

Looking at the relationship between the spaces of citizenship and tourism through an historical perspective, it can be observed that the dimension of "leisure" (as Leiper (1983) highlights, the term "tourism" would have arrived only in 1811) was originally embedded into the space of citizenship (Kalimtzis, 2017; Korstanje, 2007; White, 2016). For the ancient Greeks, scholé, "leisure", was a dimension proper to citizens and aristocrats, who were free to pursue their personal interests and hobbies in contraposition to slaves, who were not. For ancient Romans, otium, "leisure", represented the time dedicated to personal hobbies and leisure activities in contrast to the public dimension of negotium, "politics and business"; again, a dimension typical of the status of "citizen" in juxtaposition to that of "slave" (Gawthrop and Waldo, 1984; Kalimtzis, 2017; Korstanje, 2007; White, 2016). Leisure, therefore, was originally conceived as an intrinsic characteristic of being a good citizen and a free man; as a condition with a political end and a human aspiration (Kalimtzis, 2017). Cicero, in De Oratore (Cicero, 1904, pp. 1-2) uses the expression otium cum dignitate to refer to a status of security and peace with dignity conceived as a public well-being 
provided by the "best citizens who were wealthy, powerful people, who took an active part in governing the Republic" (Bragova, 2016, p. 47).

Grounded in this classical worldview, the space of leisure (so, by extension, the space of tourism) overlapped with the one of citizenship right up until the modern age; leisure was perceived as a completion of the duty of being a good citizen, proactively committed to the well-being of society via the enhancement of personal culture, moral qualities and education (Borocz, 1992; Korstanje, 2007). A transition occurred with the advent of industrial capitalism, which set the ground for the emergence of tourism as an industry of commodities consumption (Borocz, 1992; Leiper, 1979). Hence, tourism as we know it today is broadly acknowledged as organically intertwined with the development of industrial capitalism and the advent of novel technologies, infrastructures and systems of production (Borocz, 1992). Despite modern tourism having originally appeared as a social force and an agent of democratization at the service of the working class, the advent of neoliberalism profoundly changed the vision and function of tourism (Higgins-Desbiolles, 2006, 2020). As Higgins-Desbiolles (2006, p. 1194) highlights, while neoliberalism trusts that a free market will provide a set of effective economic and social benefits (Stilwell, 2002), this in practice emerges as an attempt to impose - using Gill's (1995, p. 399) words - a "market civilization" over "a global society". On a similar line, Leiper (1983, 1979), examining the historical development of the term "tourism industry", discloses how the effort to have tourism acknowledged as an "industry" is actually rooted in the purpose of gaining political weight and economic benefits via the development of such an industry.

The shift to neoliberal capitalism, therefore, appears as the turning point for the relationship between the spaces of citizenship and tourism because it effectively creates a "gap" between these two spaces. Contemporary tourists move within the space produced by neoliberal capitalism, but emerge as subjects disentangled from the space of citizenship and from the moral duties and human aspirations of a good citizen having local-global responsibility for the community they belong to (D'Eramo, 2017). Such disentanglement can be illuminated through the lens of the ancient Greek notion of hubris, understood in terms of selfish pride, lack of awareness of limits and indifference to the safety and well-being of the majority - and eventually of the self.

\section{Hubris and tourists}

In the academic literature, the concept of hubris has been mainly used with regards to entrepreneurship, business management, decision making and corporate culture (Aktas et al., 2009; Chang and Diddams, 2009; Petit and Bollaert, 2012). To the best of our knowledge, it has never been used with regards to tourism studies.

The notion of hubris depicts exaggerated pride and self-confidence. The heroes of The Iliad (Homer, 1991) and of classical Greek tragedy regularly exhibit hubris in the form of a dangerous confidence that finally provokes the wrath of the gods (Cohen, 1991; Grigoriadis, 2011). Hubris, therefore, indicates a loss of contact with reality and an overestimation of one's own competence, accomplishments, or capabilities. A person suffering from hubris tries to exceed normal human limits and - likely - violates moral codes (Owen, 2008). Hubris is usually perceived as a characteristic of an individual rather than a group, although the group the offender belongs to may suffer collateral consequences from the wrongful act. Aristotle, in his pivotal work on political philosophy the Politics (Baker, 1968), written in the 4th century BC, claims: "the man who is isolated - who is unable to share in the benefits of political association, or has no need to share because he is already self-sufficient - is not part of the polis and must, therefore, be either a beast or a god" (Morrall, 2013, p. 66). This claim chimes with the notion of hubris in that it understands the self-sufficient man as incapable of working in common and, consequently, as disconnected from his world and from the human dimension. In this sense, such a man can only be either an animal or a transcendent god. 
Hubris depicts the condition of someone lacking a sense of belonging and care for their local and global community; this makes it an interesting lens to explore the tourists' disentanglement from the space of citizens. Hubris commonly means a person's overestimation of his/her own capacity, together with a sense of supremacy that obviates the connection with others and the search for their support (Chang and Diddams, 2009; Fisher, 2015; Marquez, 2014). The person suffering from hubris is unable to perceive the boundaries of their desires and personal needs (Owen, 2008; Tulsky, 2002; Wessely, 2006). In ancient Greek literature, hubris was largely used to describe the dangerous attitude and behavior of a man keen to behave as a god, disregarding the limits of his own human condition, and thereby putting at risk both his own life and that of the community to which he belonged (Cohen, 1991; Homer, 1991; Morrall, 2013). In its essence, therefore, the notion of hubris depicts a lack of a sense of belonging to the sociological space shared with others, and thus the condition of a man falling prey to hubris resembles that of contemporary tourists living their touristic experience while being disconnected from, unaware of and uncaring for the space of the citizens in their destination. This suggests that the notion of hubris can be used to interpret contemporary tourists' behavior as akin to "bad" citizens unable to work and act for the benefit of the local and global community they belong to - as human beings - and towards whom they own a duty of care. The concept of hubris is, therefore, used here to interpret contemporary tourists' disconnection from the space of citizenship as that emerges from the contents of Italian online news media during the start of the COVID-19 global crisis.

\section{Methodology}

A qualitative narrative approach is used to examine the debate emerging in the online Italian news media immediately after the Italian government's adoption of mobility restrictions due to COVID-19. As Pasquinelli and Trunfio (2020, p. 1810) claim: "news media narratives thus participate in framing and shaping understandings of phenomena and the construction of realities. When issues have not been fully framed, and/or possible solutions to them have not been tested, the news media agenda defines their salience, influences public opinion, and shapes community consensus". Our decision to focus on online news media reflects their pivotal role in circulating information and opinions, especially during the pandemic. Narrative analysis can be applied to the contents of online news since the stories told in that media present a linear order of events together with a set of cause-effect mechanisms while depicting a social phenomenon (Fulton, 2005; Hansen, 2020; Mitchelstein and Boczkowski, 2009; Pasquinelli and Trunfio, 2020). Hence, by choosing a narrative approach, we acknowledge its strengths in exploring a social phenomenon through its representation (Czarniawska, 2004; Riessman, 1993).

The study revolves around data collected daily via three Google Alert queries set to survey the Italian online news media contents on travelers and tourists being reported for breaking the mobility restrictions related to the COVID-19 emergency. The data were collected from the 8th to the 22nd March 2020, that is the two weeks immediately following the Italian Government Decree establishing the "lockdown" of the entire Lombardy region and of fourteen other Italian provinces. This Decree identified those territories as "red areas" by establishing a number of containment measures and mobility restrictions. The lead researcher constructed three distinct sets of key words on Google Alert so as to mine online news media contents (i.e. Italian newspapers, magazines and blogs) on travelers and tourists breaking rules. The three sets of key words were, respectively: first query turisti nonostante il corona virus "tourists despite corona virus"; second query COVID-19 viaggi turismo zona rossa "COVID-19 tourists journey red areas"; third query fuga dalla zona rossa "escaping red areas". Each one of these queries provided daily alerts. The search reached data saturation after two weeks, during which time over 800 online news media contents were collated, although many of these items were the same news bounced day after day, or 
generic news and updates. Since we were specifically interested in news recounting tourists' behavior and the perceptions of that behavior, we were able to reduce the original 800 items to a total of 128 . Subsequently, we identified two main themes in the perception of tourists' behavior and their relationship with the space of local residents. These appeared to be well represented in 95 items: 56 related to Theme 1 and 39 related to Theme 2.

Using a thematic analysis of the 128 online news media contents allowed a flexible approach to the data analysis, while providing a rich and detailed account of the data (Mizrachi and Fuchs, 2016; Nowell et al., 2017; Walters, 2016). Our data analysis consisted firstly of reading, re-reading and unpacking the narrative data to develop a set of key codes that then allowed the identification of meaningful themes (Braun and Clarke, 2006). While analyzing the online media contents, we looked at factors such as the description of tourists' behavior and attitudes, their spatial relation with local residents and their breaking of the rules imposed on residents. The comparison and grouping of the codes enabled various themes to emerge; this allowed us to cast light on the divide between the space of tourism and the space of citizenship through the media perception of tourists at this unusual time. To increase confidence in the results, we each analyzed the online media contents independently, before then comparing our individual grouping of the codes.

\section{Findings}

The exploratory findings provide a first overview of how travelers and tourists were understood and presented by the Italian online news media as subjects behaving with disregard for the new measures and restrictions - like actors disconnected from the local and global community. An overview of the 128 single online news media titles is provided in Table 1.

A close examination of the online news media titles and contents discloses two main themes in the perception of tourists' behavior, and their relationship with the space of local residents: tourists taking over the space of local residents, disregarding their safety and well-being; and tourists breaking the rules set by national and local authorities (Table 2). The Google Alert queries also gathered various generic contents and updates on the COVID-19 situation, and contents bounced from one day to the other creating content repetitions. With regard to this, Table 2 provides an overview of the numbers of the online news media data analyzed for each of the two main themes.

This section discusses the findings emerging in respect to each theme in turn.

\section{Table 1 Overview of the data collection results}

\section{Table 2 Overview of the collected results with regards to the two main themes

$$
\text { 1st Query }
$$

2nd Query

3rd Query

Total
4 25

0
3 


\section{Theme 1: tourists taking over the space of local residents, disregarding their safety and well-being}

During the early phase of the COVID-19 outbreak, tourists and travelers were largely depicted through a portfolio of semantic choices stressing the intrusiveness of tourists into the space, and life, of local citizens. Tourists were thus largely narrated as acting in a parallel, disconnected, dimension to the one of local residents; taking over and "invading" a space identified as not theirs. The Italian online news media consistently used words semantically linked to the idea of overrunning and entrance, intrusion and infringement of space belonging to someone else. This insight emerges from the titles and contents of many regional and national Italian online newspapers:

[...] Schools closed, and stadiums empty for the coronavirus, but it feels like summer and tourists invade the Riviera [...].

(II Vostro Giornale, 8 March 2020)

[...] The beaches of the Ligurian Riviera have been stormed by tourists despite the institutional appeals for responsibility and the official nature of the new Prime Ministerial Decree [...].

(Telecity News 24, 9 March 2020)

Coronavirus: Courmayeur doubles its population with tourists [...] Coronavirus effect, the mayor of Courmayeur "evicts" Lombards and Piedmontese: "Those who are not residents go home $[\ldots]$.

(La Repubblica - Torino, 11 March 2020)

Coronavirus, still too many tourists in Valtellina: "Stop the flow" [...].

(II Giorno, 18 March 2020)

Tourism in the days of the coronavirus, the mayor writes to holidaymakers: "Don't come to Roburent now, we'll embrace each other after the crisis". "We will wait for you with open arms". But only when the emergency is over. Not now. The mayor tries to lock down his village, Roburent. And he writes to the tourists: "Don't travel. And don't come to us" [...] And he continues "Given the seriousness of the health emergency, I invite you not to travel. This request has the sole purpose of protecting my fellow citizens". Concluding with a promise: "We will wait for you with open arms as soon as the global emergency is over".

(La Stampa, 14 March 2020)

[...] "Last Saturday and Sunday we had the invasion of tourists, and God forbid they infected us", protests Giancarlo lanese, mayor of Comelico Superiore and president of the Mountain Union. "We want to be very hospitable, but these days we are literally afraid. You know that there are owners of second homes who come even at night and so do the tourists who have rented flats" [...] The mayor explains that the appeal "is aimed solely at protecting the health of our fellow citizens and preventing an increase in the number of sick people from jeopardizing the functioning of local hospitals" [...].

(Corriere delle Alpi, 15 March 2020)

Tourists and non-residents in the gunsight throughout Italy [...] "What are you still doing here? Go back home, you're infecting us! Go away!" From the Alps to Sicily, passing through Sardinia, the fear of Coronavirus changes and becomes fear for tourists and non-residents alike. A side effect that is infecting [...] the populations of communities that have always been devoted to tourism, which today find themselves in danger and suddenly want to close themselves off [...].

(II Sole 24 Ore, 17 March 2020) 


\section{Theme 2: tourists breaking the rules set by national and local authorities}

Tourists and travelers emerge in the Italian online news media as subjects breaking the rules set by local and national authorities during the COVID-19 crisis, and thus as lacking an appreciation of the duties, moral obligations and human aspirations arising both as citizens of a global community and as guests in local communities to whom they owe a duty of care. This is exemplified in the following extracts:

[...] Regardless of the hundreds of appeals received from all over the world in the last few days, a man and a woman from Codogno, an outbreak of coronavirus and red zone for the last 15 days, have decided to "escape" to take a few days' skiing holiday in Trentino, where they have a second home [...].

(Fan Page, 7 March 2020)

[...] Coronavirus, two tourists from Bergamo disembark in Procida in violation of the decree: immediately reembarked [...].

(II Messaggero, 9 March 2020)

Parma, escaping from the red zone for holiday in Madrid: two young people reported [...].

(Sky TG24, 9 March 2020)

Coronavirus, tourists fleeing the red zone try to board a ferry in Genoa. Rejected by the border police, they were invited to go back where they came from [...].

(Genova, 09 March 2020)

Coronavirus. Coming to the Coast for a camper holiday: reported [... .].

(Positano News, 11 March 2020)

[...] The situation that we mayors are facing is the same [...] the uncontrolled arrival of second homeowners from outside the Province and Region and the presence of tourists who believe they are on holiday [...].

(Corriere della Sera, 14 March 2020)

\section{Discussion}

Both themes revealed above highlight the impossibility of being at the same time and in the same place a citizen taking care of their daily activities and a person having leisure by travelling (D'Eramo, 2017; Tomassini and Cavagnaro, 2020). In the context of the mobility restrictions instigated during the COVID-19 outbreak, the division between the spaces of tourism and of citizenship is highlighted in the constant representation of tourists as subjects taking over the space of local residents; as invaders consuming and abusing that space, which is depicted more as a commodity than in relational terms (Massey, 2005, 2009). Tourists and travelers are largely presented as subjects spatially and temporally disengaged from the needs, safety and well-being of local residents and citizens. Hence, tourists and travelers appear akin to characters in Homer (Homer, 1991) and ancient Greek tragedy who have lost awareness of the boundaries inherent in the human condition and its space (Baker, 1968; Cohen, 1991; Owen, 2008). By extension, they appear as irresponsible citizens, disconnected from any sense of belonging to a local or global community, and from a space to which they owe a duty of care. 
These findings chime with a growing body of literature urging the need to build a futureproof sustainable tourism able to embrace the sociological space of local communities and inhabitants, as well as their well-being and security (Higgins-Desbiolles, 2020; Jamal, 2019; Jover and Díaz-Parra, 2020; Sun et al., 2020). The COVID-19 crisis has further strengthened calls to reflect on tourism's local-global responsibilities and actions in a world with pandemics (Jamal and Budke, 2020). By revealing a selfish attitude and indifference for rules and moral duties, tourists are narrated as hubristic individuals unable to take part in a community, a polis (Baker, 1968; Morrall, 2013; Owen, 2008; Tulsky, 2002; Wessely, 2006). The tourists' inability to understand and pursue a common good of safety and well-being, as well as their violation of moral duties and local and national rules, is here interpreted as the hubris of a "bad" citizen who causes dangerous consequences to the local and global community (Chang and Diddams, 2009; Marquez, 2014; Tulsky, 2002). By highlighting those tourists and travelers breaking rules during the COVID-19 outbreak, the online news media highlight their disengagement from the space of citizenship with its rules and moral obligations. This, therefore, casts light on a novel possible understanding of the 21st century phenomenon of "free-range badly-behaved tourists" (Higgins-Desbiolles, 2019), and the unbalanced power relations (Bianchi, 2018; Burrai et al., 2019; Higgins-Desbiolles et al., 2019; Jamal, 2019) and "power-geometries" (Massey, 2005, 2009) that contemporary tourism has provoked within the sociological space of citizenship. In this study, the interplay of theoretical concepts of hubris and the sociology of space allows an exploration of a novel ontic foundation from whence tourists are investigated not in behavioral terms - as "freerange badly-behaved tourists" (Higgins-Desbiolles, 2019) - but as human subjects not belonging to the same sociological space as citizens. As such, they are perceived and narrated as belonging to a sociological space of leisure that lacks the complexity of the interactions between humans and space, and the implications that arise from that complexity.

\section{Conclusion}

In this study we constructed novel theoretical ground through which to articulate the "tourism syndrome" of the 21st century globalized world, and thence to establish a foundation for a future sustainable tourism rooted in the space of citizenship. We draw on theories of the sociology of space (Lefebvre, 1984; Massey, 2005, 2009) and the ancient Greek notion of hubris (Baker, 1968; Cohen, 1991; Homer, 1991; Owen, 2008). This theoretical framework allowed us to cast light on the growing divide between the sociological spaces of tourists and of local residents; exploring tourists not just as badly-behaved subjects but as hubristic subjects, ontologically belonging to a neoliberal leisure space disengaged from the citizenship space. On a theoretical level, our study contributes to further knowledge in the field of critical tourism studies and offers new directions to plan and construct a future-proof sustainable tourism, largely dependent on the capacity to reconnect tourism and citizenship space. On a practical level, our study emphasizes the importance of tourism forms of production and consumption that remain focused on the needs, safety and well-being of the localglobal community we all belong to, both as tourists and citizens. Hence, through the online news media's understanding and narrativization of tourists during the COVID-19 outbreak, we recognize the importance of resisting neoliberal ways of conceiving of tourism by reconnecting leisure activities to collective well-being and safety. Finally, we acknowledge that our research has some limitations that call for further investigation. There is no seeking of universal principles here; the focus on a specific context and historical moment acknowledges that this research needs a broader context or longer timespan in an attempt to universalize what is, of necessity, specific and particular. As we limited our research to the Italian context during the peak of the initial COVID-19 outbreak, further research should explore how online news media from different geographical contexts present tourists and travelers during global crises, national 
emergencies and sensitive contexts or situations. Moreover, further research should apply diverse methodological approaches to explore the representation of tourists and travelers in the media, and the relationship between the notion of hubris and the perception and narrativization of tourists and travelers within the sociological space of citizenship.

\section{References}

Aktas, N., De Bodt, E. and Roll, R. (2009), "Learning, hubris and corporate serial acquisitions", Journal of Corporate Finance, Vol. 15 No. 5, pp. 543-561, doi: 10.2139/ssrn.721882.

Baker, E. (1968), The Politics of Aristotle, Oxford University Press.

Bauman, Z. (2000), Liquid Modernity, Cambridge.

Bianchi, R. (2018), "The political economy of tourism development: a critical review", Annals of Tourism Research, Vol. 70, pp. 88-102, doi: 10.1016/j.annals.2017.08.005.

Boluk, K.A., Cavaliere, C.T. and Higgins-Desbiolles, F. (2019), "A critical framework for interrogating the united nations sustainable development goals 2030 agenda in tourism", Journal of Sustainable Tourism, Vol. 27 No. 7, pp. 847-864, doi: 10.1080/09669582.2019.1619748.

Borocz, J. (1992), "Travel-capitalism: the structure of Europe and the advent of the tourist", Comparative Studies in Society and History, Vol. 34 No. 4, pp. 708-741, doi: 10.1017/s0010417500018065.

Bragova, A. (2016), "The concept cum dignitate otium in Cicero's writings", Studia Antiqua et Archaeologica, Vol. 22 No. 1, pp. 45-49.

Braun, V. and Clarke, V. (2006), "Using thematic analysis in psychology", Qualitative Research in Psychology, Vol. 3 No. 2, pp. 77-101, doi: 10.1191/1478088706qp063oa.

Burrai, E., Buda, D.-M. and Stanford, D. (2019), "Rethinking the ideology of responsible tourism", Journal of Sustainable Tourism, Vol. 27 No. 7, pp. 992-1007, doi: 10.1080/09669582.2019.1578365.

Celata, F. and Romano, A. (2020), "Overtourism and online short-term rental platforms in Italian cities", Journal of Sustainabe Tourism, doi: 10.1080/09669582.2020.1788568.

Chang, G. and Diddams, M. (2009), "Hubris or humility: cautions surrounding the construct and selfdefinition of authentic leadership", Academy of Management Proceedings, Vol. 2009 No. 1, doi: 10.5465/ ambpp.2009.44247841.

Cheer, J.M., Milano, C. and Novelli, M. (2019), "Tourism and community resilience in the Anthropocene: accentuating temporal overtourism", Journal of Sustainable Tourism, Vol. 27 No. 4, pp. 554-572, doi: 10.4324/9781003000099-10.

Cicero, M.T. (1904), De Oratore, Book 1, Methuen and Company.

Cohen, D. (1991), "Sexuality, violence, and the Athenian law of Hubris", Greece and Rome, Vol. 38 No. 2, pp. 171-188, doi: 10.1017/s001738350002355x.

Czarniawska, B. (2004), Narratives in Social Science Research, Sage, doi: 10.4135/9781849209502.

D’Eramo, M. (2017), II Selfie Del Mondo. Indagine Sull'età Del Turismo, Feltrinelli.

Diaz-Parra, I. and Jover, J. (2020), "Overtourism, place alienation and the right to the city: insights from the historic centre of Seville, Spain", Journal of Sustainable Tourism, Vol. 29 Nos 2/3, doi: 10.1080/ 09669582.2020.1717504.

Fisher, N.R.E. (2015), Greek Law, Greek Literature, Greek Myth and Religion, Philosophy, Oxford University Press, doi: 10.1093/acrefore/9780199381135.013.3172.

Franklin, A. (2003), "The tourist syndrome: an interview with Zygmunt Bauman", Tourist Studies, Vol. 3 No. 2, pp. 205-217, doi: 10.1177/1468797603041632.

Fulton, H. (2005), "Print news as narrative", in Fulton, H., Huisman, R., Murphet, J. and Dunn, A. (Eds), Media and Narrative, Cambridge University Press, pp. 218-244, doi: 10.1017/ cbo9780511811760.016.

Gainsforth, S. (2019), Airbnb Città Merce. Storie di Resistenza Alla Gentrificazione Digitale, DeriveApprodi. 
Gawthrop, L.C. and Waldo, D. (1984), "Civis, civitas, and civilitas: a new focus for the year 2000”, Public Administration Review, Vol. 44, pp. 101-111, doi: 10.2307/975549.

Gill, S. (1995), "Globalisation", Millennium: Journal of International Studies, Vol. 24 No. 3, pp. 399-423, doi: 10.1177/03058298950240030801.

Gössling, S., McCabe, S. and Chen, N. (2020), "A socio-psychological conceptualisation of overtourism", Annals of Tourism Research, Vol. 84, doi: 10.1016/j.annals.2020.10297623.

Grigoriadis, I.N. (2011), "Greek tragedy”, World Policy Journal, Vol. 28 No. 2, pp. 101-109.

Hall, C.M. and Page, S. (2010), "The contribution of Neil Leiper to tourism studies", Current Issues in Tourism, Vol. 13 No. 4, pp. 299-309, doi: 10.1080/13683500.2010.482652.

Hansen, T. (2020), "Media framing of Copenhagen tourism: a new approach to public opinion about tourists", Annals of Tourism Research, Vol. 84, p. 102975, doi: 10.1016/j. annals.2020.10297.

Higgins-Desbiolles, F. (2006), "More than an 'industry': the forgotten power of tourism as a social force", Tourism Management, Vol. 27 No. 6, pp. 1192-1208, doi: 10.1016/j.tourman.2005.05.020.

Higgins-Desbiolles, F. (2020), "Socialising tourism for social and ecological justice after COVID-19", Tourism Geographies, Vol. 22 No. 3, pp. 610-623, doi: 10.1080/14616688.2020.1757748.

Higgins-Desbiolles, F., Carnicelli, S., Krolikowski, C., Wijesinghe, G. and Boluk, K. (2019), "Degrowing tourism: rethinking tourism", Journal of Sustainable Tourism, Vol. 27 No. 12, pp. 1926-1944, doi: 10.1080/ 09669582.2019.1601732.

Higgins-Desbiolles, F. (2019), "Tourists behaving badly are a threat to global tourism, and the industry is partly to blame", The Conversation, available at: http://theconversation.com/tourists-behaving-badly-area-threat-to-global-tourism-and-the-industry-is-partly-to-blame-112398

Homer (1991), The lliad, Penguin.

Jamal, T. (2019), Justice and Ethics in Tourism, Earthscan, doi: 10.4324/9781315162942.

Jamal, T. and Budke, C. (2020), "Tourism in a world with pandemics: local-global responsibility and action”, Journal of Tourism Futures, Vol. 6 No. 2, pp. 181-188, doi: 10.1108/jtf-02-2020-0014.

Jover, J. and Díaz-Parra, I. (2020), "Who is the city for? Overtourism, lifestyle migration and social sustainability", Tourism Geographies, doi: 10.1080/14616688.2020.1713878.

Kalimtzis, K. (2017), An Inquiry into the Philosophical Concept of Scholê: Leisure as a Political End, Bloomsbury Publishing, doi: 10.5040/9781474237963.

Kirtsoglou, E. and Theodossopoulos, D. (2004), “'They are taking our culture away': tourism and culture commodification in the Garifuna community of Roatan", Critique of Anthropology, Vol. 24 No. 2, pp. 135-157, doi: 10.1177/0308275×04042650.

Korstanje, M.E. (2007), "The origin and meaning of tourism: etymological study", e-Review of Tourism Research, Vol. 5 No. 5, pp. 100-108.

Lefebvre, H. (1976), Survival of Capitalism, Allison and Busby.

Lefebvre, H. (1984), The Production of Space, Blackwell Pub.

Leiper, N. (1979), "The framework of tourism: towards a definition of tourism, tourist, and the tourist industry", Annals of Tourism Research, Vol. 6 No. 4, pp. 390-407, doi: 10.1177/ 004728758001900184

Leiper, N. (1983), "An etymology of 'tourism'”, Annals of Tourism Research, Vol. 10 No. 2, pp. 277-280, doi: 10.1016/0160-7383(83)90033-6.

Lew, A., Cheer, J.M., Haywood, M., Brouder, P. and Salazar, N.B. (2020), "Visions of travel and tourism after the global COVID-19 transformation of 2020", Tourism Geographies, Vol. 22 No. 3, pp. 455-466.

Marquez, X. (2014), "Hubris", The Encyclopedia of Political Thought, American Cancer Society, pp. $1712-1713$.

Massey, D. (1992), "Politics and space/time”, New Left Review, Vol. 196 No. Nov/Dec, pp. 65-84.

Massey, D. (1999), "Imagining globalization: power-geometries of time-space", in Brah, A., Hickman, M. J. and Ghaill, M.M. (Eds), Global Futures: Migration, Environment and Globalization. Explorations in Sociology, Palgrave Macmillan, pp. 27-44, doi: 10.1057/9780230378537_2. 
Massey, D. (2005), For Space, Thousand Oaks.

Massey, D. (2009), "Concepts of space and power in theory and in political practice", Documents D’anàlisi Geogràfica, No. 55, pp. 15-26.

Milano, C., Cheer, J.M. and Novelli, M. (2019), Overtourism: Excesses, Discontents and Measures in Travel and Tourism, Cabi.

Milano, C., Novelli, M. and Cheer, J.M. (2019), "Overtourism and tourismphobia: a journey through four decades of tourism development, planning and local concerns", Tourism Planning and Development, Vol. 16 No. 4, pp. 353-357.

Mitchelstein, E. and Boczkowski, P.J. (2009), "Between tradition and change: a review of recent research on online news production", Journalism, Vol. 10 No. 5, pp. 562-586, doi: 10.1177/ 1464884909106533.

Mizrachi, I. and Fuchs, G. (2016), "Should we cancel? An examination of risk handling in travel social media before visiting Ebola-free destinations", Journal of Hospitality and Tourism Management, Vol. 28, pp. 59-65, doi: 10.1016/j.jhtm.2016.01.009.

Morrall, J.B. (2013), Aristotle, Routledge.

Morris, R.C. (2008), "The pursuit of leisure and the rise of the Roman villa", The New York Times, available at: www.nytimes.com/2008/09/12/arts/12iht-otium.1.16069552.html

Nowell, L.S., Norris, J.M., White, D.E. and Moules, N.J. (2017), "Thematic analysis: striving to meet the trustworthiness criteria", International Journal of Qualitative Methods, Vol. 16 No. 1, pp. 1-13, doi: 10.1177/1609406917733847.

Owen, D. (2008), "Hubris syndrome", Clinical Medicine, Vol. 8 No. 4, pp. 428-432, doi: 10.7861/ clinmedicine.8-4-428.

Pasquinelli, C. and Trunfio, M. (2020), "Overtouristified cities: an online news media narrative analysis", Journal of Sustainable Tourism, Vol. 28 No. 11, pp. 1805-1824, doi: 10.1080/ 09669582.2020.1760871.

Petit, V. and Bollaert, H. (2012), "Flying too close to the sun? Hubris among CEOs and how to prevent it", Journal of Business Ethics, Vol. 108 No. 3, pp. 265-283, doi: 10.1007/s10551-011-1097-1.

Phi, G.T. (2019), "Framing overtourism: a critical news media analysis", Current Issues in Tourism, Vol. 23 No. 17, pp. 2093-2097, doi: 10.1080/13683500.2019.1618249.

Riessman, C.K. (1993), Narrative Analysis, Sage.

Stilwell, F. (2002), "The state of political economy", Journal of Australian Political Economy, Vol. 50, pp. 5-9.

Sun, J., Zhang, S. and Ji, M. (2020), "Revisiting the impacts of tourism from the perspective of social space production: an ethnological study of the Muslim community in Sanya, Hainan province, China", Current Issues in Tourism, Vol. 23 No. 15, pp. 1845-1863, doi: 10.1080/ 13683500.2019 .1653266 .

Tomassini, L. and Cavagnaro, E. (2020), "The novel spaces and power-geometries in tourism and hospitality after 2020 will belong to the 'local'", Tourism Geographies, Vol. 22 No. 3, pp. 713-719, doi: 10.1080/14616688.2020.1757747.

Tulsky, J.A. (2002), "Hope and hubris", Journal of Palliative Medicine, Vol. 5 No. 3, pp. 339-341, doi: 10.1089/109662102320135225.

UNWTO (2020), "International tourism growth continues to outplace the global economy", UNWTO, available at: https://unwto.org/international-tourism-growth-continues-to-outpace-theeconomy

Walters, T. (2016), "Using thematic analysis in tourism research", Tourism Analysis, Vol. 21 No. 1, pp. 107-116, doi: 10.3727/108354216×14537459509017.

Wessely, S. (2006), "Commentary: the psychiatry of hubris", Journal of the Royal Society of Medicine, Vol. 99 No. 11, pp. 552-553, doi: 10.1177/014107680609901111.

White, D. (2016), "The gift of philosophy: between otium and negotium", The European Legacy, Vol. 21 No. 1, pp. 71-78. 


\section{Further reading}

Hall, C.M. (2002), "Travel safety, terrorism and the media: the significance of the issue-attention cycle", Current Issues in Tourism, Vol. 5 No. 5, pp. 458-466, doi: 10.1080/13683500208667935.

Hall, C.M. (2003), "Tourism issues, agenda setting and the media", E-Review of Tourism Research, Vol. 1 No. 3, pp. $42-45$.

Schweinsberg, S., Darcy, S. and Cheng, M. (2017), "The agenda setting power of news media in framing the future role of tourism in protected areas", Tourism Management, Vol. 62, pp. 241-252, doi: 10.1016/j. tourman.2017.04.011.

\section{Corresponding author}

Lucia Tomassini can be contacted at: tomassini.lucia@gmail.com

For instructions on how to order reprints of this article, please visit our website: www.emeraldgrouppublishing.com/licensing/reprints.htm

Or contact us for further details: permissions@emeraldinsight.com 